Evelin Grage-Griebenow',

Jaroslaw Baran',

Harald Loppnow',

Marek Los $^{3}$,

Martin Ernst',

Hans-Dieter Flad ${ }^{1}$ and

Juliusz Pryjma ${ }^{2}$

${ }^{1}$ Forschungszentrum Borstel, Department of Immunology and Cell Biology, Borstel, Germany

2 Jagiellonian University, Institute of Molecular Biology, Cracow, Poland

${ }^{3}$ Deutsches Krebsforschungszentrum, Heidelberg, Germany

\section{An Fcy receptor I (CD64)-negative subpopulation of human peripheral blood monocytes is resistant to killing by antigen-activated CD4-positive cytotoxic $T$ cells}

\begin{abstract}
It has been demonstrated that in monocyte/ $T$ cell co-cultures activated with recall antigens, cytotoxic $\mathrm{T}$ cells were generated which are able to reduce the number of antigen-presenting monocytes. In previous studies we could show that a minor subset of monocytes, the Fc $\gamma$ receptor I-negative (CD64-) monocytes, exhibits significantly higher antigen-presenting capacity than the main population of monocytes $(>90 \%)$ which are Fcy receptor I-positive $\left(\mathrm{CD}^{+} 4^{+}\right)$. Therefore, we addressed the question whether they are also differentially susceptible to T cell-mediated killing. In the present study we demonstrate that the $\mathrm{CD}^{-}$monocyte subset is more resistant to killing by antigen-activated $\mathrm{T}$ cells than $\mathrm{CD}^{+} 4^{+}$monocytes, as indicated by a higher viability and recovery of $\mathrm{CD} 64^{-}$ monocytes. This mechanism involves CD95 (Fas) antigen, since monocyte death in co-cultures with antigen-activated $\mathrm{T}$ cells could be partially reduced by blocking anti-Fas monoclonal antibodies $(\mathrm{mAb})$. In agreement with this finding, although $\mathrm{CD} 95$ antigen was expressed on $\mathrm{CD} 64^{+}$and $\mathrm{CD}^{-} 4^{-}$monocytes at comparable levels, killing of $\mathrm{CD}^{-}$monocytes by activating anti-Fas $\mathrm{mAb}$ was lower than of $\mathrm{CD} 64^{+}$monocytes.
\end{abstract}

\section{Introduction}

The effective activation of $T$ cells by triggering the $\mathrm{T}$ cell receptor and interaction with co-stimulatory molecules on antigen-presenting cells (APC) requires several hours [1]. Therefore, the generation of CD4-positive $\left(\mathrm{CD}^{+}\right)$cytotoxic $\mathrm{T}$ cells which are able to kill APC $[2-5]$ is considered to represent an immunoregulatory mechanism. Moreover, APC resistant to killing by cytotoxic T cells may be responsible for an enhanced immune response [6,7]. The mechanism of killing involves interaction of CD95 (Fas/APO-1) antigen and Fas ligand which leads to apoptosis $[8,9]$. Recently, we found $\mathrm{CD}^{+} \mathrm{CD} 45 \mathrm{RO}^{+}$cytotoxic $\mathrm{T}$ cells able to induce apoptosis of APC in cultures of peripheral blood lymphocytes activated by the recall antigens tetanus toxoid and the purified protein derivative of tuberculin (PPD) [10]. Since peripheral blood monocytes are heterogeneous in phenotype and in their capacity to function as APC [11], the question arises whether monocyte subpopulations are equally susceptible to $T$ cell-mediated killing. In particular, monocytes lacking the Fcy receptor I (CD64-), comprising less than $10 \%$ of all monocytes, were found to be more effective as APC than the predominant population of $\mathrm{CD} 4^{+}$monocytes [12]. Thus, we investigated whether

[I 16611]

Received January 13, 1997; in final revised form June 16, 1997; accepted June 18, 1997.

Correspondence: Evelin Grage-Griebenow, Department of Immunology and Cell Biology, Forschungszentrum Borstel, Parkallee 22, D-23845 Borstel, Germany

Fax: +49-4537-188-404

Abbreviations: CFSE: 5-(6)-Carboxyfluorescein succinimidylester 7-AAD: 7-Aminoactinomycin D MO: Monocytes

Key words: CD64-negative monocytes / Cytotoxic T cell / Resistance to killing / Recall antigen / Apoptosis
$\mathrm{CD}^{+} 4^{+}$and $\mathrm{CD}^{-} 4^{-}$monocytes differ with respect to their survival in antigen-activated co-cultures with autologous $\mathrm{T}$ cells, expression of Fas antigen, and their susceptibility to Fas-mediated killing. The data presented show that $\mathrm{CD} 64^{-}$ monocytes are more resistant to killing by PPD-activated T cells and to apoptosis induced by anti-Fas APO-1 mAb.

\section{Materials and methods}

\subsection{Culture medium}

All cell cultures were performed in RPMI 1640 medium supplemented with $100 \mathrm{U} / \mathrm{ml}$ penicillin $\mathrm{G}, 100 \mu \mathrm{g} / \mathrm{ml}$ streptomycin, $2 \mathrm{mmol} / / \mathrm{L}$-glutamine and $10 \%$ heat-inactivated FCS, all obtained from Biochrom (Berlin, Germany).

\subsection{Cell preparations}

Purified monocytes, lymphocytes, and subsets of monocytes were isolated from peripheral blood of normal healthy donors. For stimulation experiments with PPD, only blood from tuberculin skin test-positive donors was taken. Peripheral blood mononuclear cells (PBMC) were first isolated from heparinized whole blood by Ficoll/Isopaque $(1.077 \mathrm{~g} / \mathrm{ml}$, Pharmacia, Freiburg, Germany) density gradient centrifugation $\left(465 \times \mathrm{g}, 45 \mathrm{~min}, 22^{\circ} \mathrm{C}\right)$. PBMC, harvested from the interface, were washed once in HBSS (Biochrom) $\left(465 \times \mathrm{g}, 15 \mathrm{~min}, 4^{\circ} \mathrm{C}\right)$ and once in HBSS through an FCS cushion $\left(298 \times \mathrm{g}, 15 \mathrm{~min}, 4^{\circ} \mathrm{C}\right)$ to remove cell fragments and residual platelets. Monocytes and lymphocytes were further separated by counterflow centrifugation using the JE-6B-elutriator system (Beckman Instruments Inc., Palo Alto, CA) as described [12]. The purity of the resulting fraction of pooled monocytes was approximately $90 \pm 3 \%$ and that of the pooled lymphocytes $99 \pm 2 \%$ as examined by $\alpha$-naphthyl acetate esterase or immunofluorescence staining with anti-CD14-specific 
mAb (MO-P9, IgG2b, Becton Dickinson, Heidelberg, Germany). For the isolation of $\mathrm{CD}^{+} 4^{+}$and $\mathrm{CD}^{-} 4^{-}$subsets from monocytes, the elutriation-derived, purified monocytes were directly labeled with FITC-conjugated antiCD64 mAb (clone 22, IgG1, Medarex Inc., Annandale, $\mathrm{NJ})$ which recognizes an epitope of the Fcy receptor I on human monocytes outside the $\mathrm{Fc}$ binding region [13] and, therefore, does not block the Fc receptor function. Briefly, monocytes were incubated with FITC-conjugated antiCD64 mAb for 15-30 min on ice in PBS (Merck, Darmstadt, Germany), washed once in ice-cold PBS through an FCS cushion, and finally resuspended in ice-cold PBS. Then $\mathrm{CD} 64^{+}$and $\mathrm{CD} 64^{-}$monocytes were separated by cell sorting using cytofluorograf $50 \mathrm{H}$ cell sorter system (Ortho Diagnostics Systems, Westwood, MA). Monocytes stained with FITC-conjugated control IgG1 (Dako, Hamburg, Germany) were used as negative control to define sorting criteria. Cell fragments could be gated out according to their reduced forward and side scatter signals compared to intact cells. The subsequent flow cytometric reanalysis revealed a purity of $98 \pm 1 \%$ for the $\mathrm{CD}^{+} 4^{+}$sorted monocytes and of $76 \pm 5 \%$ for the $\mathrm{CD}^{-} 4^{-}$sorted subset. In each experiment unstained elutriated monocytes were further depleted of residual lymphocytes by cell sorting using the light scatter signals as sort criteria, since both the forward scatter and side scatter signals are stronger in monocytes than in lymphocytes. These sorted monocytes termed "unseparated monocytes" were $95 \pm 2 \%$ pure, as judged by $\alpha$-naphthyl acetate esterase staining. In most of the experiments elutriated lymphocytes were further depleted of $B$ cells, HLA-DR ${ }^{+}$cells, and NK cells by magnetic cell sorting (MACS) as described by Abts et al. [14] and Miltenyi et al. [15]. Briefly, lymphocytes $\left(10^{7}\right.$ cells $\left./ \mathrm{ml}\right) \mathrm{kept}$ on ice were stained in three consecutive incubation steps of 15 min each: first with anti-CD20 (B-Ly1, IgG1, Dako, Hamburg, Germany), anti-HLA-DR (B8.12.2., IgG2b, Dianova, Hamburg, Germany), and anti-CD16 (3G8, IgG1, Dianova) fluorochrome-unconjugated $\mathrm{mAb}$ $\left(50-100 \mu \mathrm{l} \mathrm{mAb} / 10 \times 10^{7}\right.$ cells $)$, then with biotinylated goat anti-mouse IgG (Dianova) diluted $1: 100$, and finally with streptavidin-conjugated magnetic microbeads (Miltenyi Biotech GmbH, Bergisch Gladbach, Germany). Each incubation step was followed by washing the cells through an FCS cushion. The cells were then adjusted to $20 \times 10^{6}$ cells $/ \mathrm{ml}$ with medium containing $1 \%$ BSA followed by magnetic cell separation through an appropriate column (Miltenyi Biotech equilibrated as described by the manufacturer. The efficiency of depletion was proven by fluorescence anlysis of the "non-magnetic" fraction of cells stained with PE-conjugated anti-CD3, anti-CD19, antiCD16, and anti-HLA-DR mAb. Subsequent investigation by flow cytometry revealed an enrichment from $69 \pm 6 \%$ to $92 \pm 3 \% \mathrm{CD}^{+} \mathrm{T}$ cells and contamination with $\mathrm{CD} 19^{+}$, CD $16^{+}$or HLA-DR ${ }^{+}$cells did not exceed $2 \pm 2 \%$.

\subsection{Cell culture and stimulation with PPD}

Unseparated, $\mathrm{CD} 64^{+}$, or CD64- monocytes $\left(2.5 \times 10^{4}\right)$ were co-cultured with purified T cells $\left(2 \times 10^{5}\right)$ in Falcon 2057 polystyrene tubes in $250 \mu \mathrm{l}$ of culture medium in the presence or absence of PPD (Statenserum Institut, Copenhagen, Denmark) at a final concentration of $10 \mu \mathrm{g} / \mathrm{ml}$. For determination of IFN- $\gamma$, culture supernatants were harvested after 3 days of culture.

\subsection{Labeling of cells with 5-(6)-carboxyfluorescein succinimidylester (CFSE)}

To differentiate between monocytes and lymphocytes during flow cytometric analysis, two main criteria were used. First, lymphocytes were discriminated from monocytes due to their smaller forward and side scatter signals. Second, in the majority of experiments monocytes or lymphocytes were labeled before co-culture with CFSE [16, 17]. This fluorochrome passes the cell membrane and binds to cytoplasmatic proteins. Freshly isolated monocytes or lymphocytes $\left(1 \times 10^{7} / \mathrm{ml}\right)$ were incubated with CFSE at a final concentration of $5 \mu \mathrm{M}$ for $15 \mathrm{~min}$ in PBS at $37^{\circ} \mathrm{C}$ and $5 \%$ $\mathrm{CO}_{2}$, washed twice in ice-cold PBS through an FCScushion, and resuspended in culture medium. These cells were then co-cultured with unstained monocytes or lymphocytes for $72 \mathrm{~h}$ in the presence or absence of stimuli. Cells stained in this way had higher fluorescence intensity than anti-CD64-FITC-stained CD64 ${ }^{+}$cells. Moreover, the intensity of CFSE-stained cells decreased only slightly during the culture period of $72 \mathrm{~h}$.

\subsection{Evaluation of cell viability}

To detect dead or apoptotic cells in cell cultures, 7aminoactinomycin D (7-AAD) (Sigma, Deisenhofen, Germany) was used as described elsewhere [10]. Briefly, after harvesting of culture supernatants and prior to flow cytometry cells were incubated on ice with $20 \mu \mathrm{g} / \mathrm{ml}$ of 7-AAD and the cells were analyzed $15 \mathrm{~min}$ after labeling. We have shown previously that, when applying this technique to monocytes co-cultured with $T$ cells, staining is predominantly found in apoptotic cells as verified by the terminal deoxynucleotidyl transferase assay [10]. The use of this dye in combination with CFSE-staining enabled us to discriminate apoptotic cells (red fluorescence) from non-apoptotic cells (no red fluorescence) within CFSE-stained (green fluorescence) or CFSE-unstained lymphocytes or monocytes. In addition, due to different light emission spectra of 7$\mathrm{AAD}$ and $\mathrm{PE}[18]$ 7-AAD was used in combination with $\mathrm{PE}$-conjugated $\mathrm{mAb}$. In these cases the cells were first labeled with PE-conjugated $\mathrm{mAb}$ and then incubated with 7-AAD for $15 \mathrm{~min}$ before flow cytometric analysis.

\subsection{Determination of the effect of blocking and activating anti-CD95 $\mathrm{mAb}$ on monocyte killing}

For Fas blocking experiments, unseparated PBMC $\left(2 \times 10^{5} / 200 \mu \mathrm{l}\right)$ were cultured in the presence or absence of PPD for $72 \mathrm{~h}$. Fifteen minutes prior to stimulation with PPD $1 \mu \mathrm{g} / \mathrm{ml}$ of blocking IgG1 anti-Fas mAb ZB4 [19] was added to the cultures. As a negative control $1 \mu \mathrm{g} / \mathrm{ml}$ of an IgG1 isotype control mAb was added to parallel cultures. For the induction of Fas (CD95)-induced apoptosis, unseparated monocytes $\left(1 \times 10^{6} / 500 \mu \mathrm{l}\right)$ and isolated CD64and $\mathrm{CD} 64^{+}$monocyte subsets were cultured alone for $12 \mathrm{~h}$ in the presence or absence of $2.5-10 \mu \mathrm{g} / \mathrm{ml}$ of activating IgG3 anti-CD95 mAb APO-1 [20] purified on protein Gagarose from the supernatant of SB6-2B1 cells. As a negative control, cells in parallel cultures were incubated with anti-Ki-67 (kindly provided by Prof. J. Gerdes, Forschungszentrum Borstel, Germany), an IgG3 mAb specific for an intracellular proliferation-associated nuclear anti- 
gen. In both kinds of experiments monocyte viability was determined by staining with 7-AAD at the end of the culture period and subsequent flow cytometry, as described in Sect. 2.5.

\subsection{Anti-CD95 staining of cells by immunofluorescence labeling}

For the determination of CD95 expression cells were labeled with three different anti-Fas mAb: PE-conjugated anti-CD95 mAb (DX2, IgG1, PharMingen, Hamburg, Germany) at a dilution of $1: 10$, or the unconjugated $m A b$ SB6-2B (IgG3), or ZB4 (IgG1, Immunotech, Hamburg, Germany) at a final concentration of $10 \mu \mathrm{g} / \mathrm{ml}$ in PBS for $15 \mathrm{~min}$ on ice. As negative controls, cells were incubated with PE-conjugated and unconjugated IgG1 control mAb (Dako, Hamburg, Germany) or unconjugated IgG3 anti$\mathrm{Ki}-67 \mathrm{mAb}$. Then the cells were washed once in ice-cold PBS through an FCS-cushion $\left(298 \times \mathrm{g}, 10 \mathrm{~min}, 4^{\circ} \mathrm{C}\right)$ and resuspended in PBS. Cells stained with unconjugated $\mathrm{mAb}$ were incubated with PE-conjugated goat $\mathrm{F}\left(\mathrm{ab}^{\prime}\right)_{2}$ antimouse $\mathrm{IgG}_{\mathrm{Fc}}$ in a second step and washed as described before. Finally, cells were fixed with $1.5 \%$ paraformaldehyde-PBS solution and kept in the dark at $4^{\circ} \mathrm{C}$ until flow cytometric analysis.

\subsection{Flow cytometric analysis}

The analysis of immunofluorescence-stained cells was always performed with the FACStar Plus (Becton Dickinson, Heidelberg, Germany) equipped with an argon laser.

\subsection{Measurement of IFN- $\gamma$ in culture supernatants}

The concentrations of IFN- $\gamma$ in supernatants were determined using a quantitative ELISA, kindly provided by Dr.
H. Gallati (Hoffmann-LaRoche, Basel, Switzerland). The assay was carried out as recommended by the manufacturer (Hoffmann-LaRoche) and as described by Gallati [21].

\section{Results}

\subsection{CD64- monocytes survive better in PPD-stimulated cultures than unseparated or $\mathrm{CD} 64^{+}$monocytes}

To compare the survival of $\mathrm{CD} 64^{+}$and $\mathrm{CD} 64^{-}$monocytes in PPD-stimulated cultures, cell viability was evaluated by exposure to 7-AAD as described in Sect. 2.5. To distinguish between monocytes and $\mathrm{T}$ cells, one population was labeled with CFSE before the co-cultures were set up. Such treatment had no apparent influence on monocyte APC function, nor on T cell response. As shown in Table 1, the PPD-induced IFN- $\gamma$ release in cultures of CFSEstained monocytes or $\mathrm{T}$ cells was comparable to that of parallel cultures of CFSE-unstained cells. Flow cytometric analysis of these monocyte/T cell co-cultures revealed a clear distinction of four cell populations which differ in green (CFSE) versus red (DNA staining by 7-ADD) fluorescence (Fig. 1). Such analysis enabled the calculation of apoptotic $\left(7-\mathrm{AAD}^{+}\right)$cells within monocytes. As shown in Table 2, in cultures to which unseparated or $\mathrm{CD} 64^{+}$monocytes had been added the proportion of 7- $\mathrm{AAD}^{+}$monocytes increased after PPD stimulation [ratio PPD/none (unseparated) $=1.68 \pm 0.33 ;$ PPD/none $\left(\mathrm{CD} 64^{+}\right)=$ $2.98 \pm 1.83$ ]. In contrast, in cultures with $\mathrm{CD}^{-} 4^{-}$monocytes the ratio (PPD/none) did not change (1.05 \pm 0.19$)$. Thus the increase of monocyte apoptosis in activated cultures was higher in unseparated monocytes and their $\mathrm{CD}^{+}{ }^{+}$subset than inCD64 ${ }^{-}$monocytes. In addition, the monocyte recovery presented as percentage of CFSEstained monocytes (Fig. 1, number in parenthesis) within total cells collected was usually lower in PPD-activated

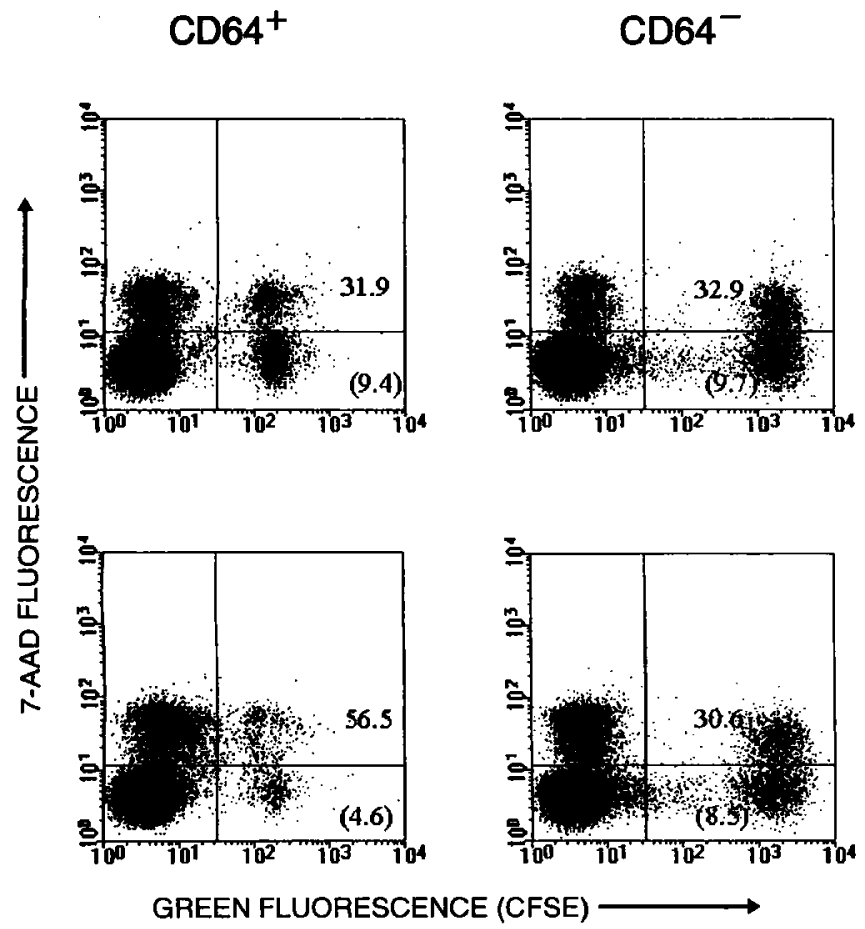

unstimulated

PPD-activated

Figure 1. Flow cytometric analysis of monocyte viability and recovery in monocyte/ $\mathrm{T}$ cell cocultures. T cells $\left(2 \times 10^{5}\right)$ were co-cultured with monocyte subsets $\left(2.5 \times 10^{4}\right)$ in $250 \mu \mathrm{l}$ of culture medium for $72 \mathrm{~h}$. Dot plots of unstimulated control cultures (upper) and PPDactivated cultures (bottom) are shown. Monocytes were labeled before culture with CFSE (xaxis, green fluorescence), and prior to flow cytometric analysis cultures were preincubated with 7-AAD (red fluorescence, y-axis) which enabled calculation of the monocyte viability (\% red cells within population of green cells, upper numbers in each dot plot). The calculated proportion of monocytes in culture at time $0 \mathrm{~h}$ was $11.1 \%$, the percentage of monocytes within the monocyte/T cell co-cultures is given in parenthesis (calculated as \% of green cells in the whole population). 
Table 1. The influence of CFSE labeling of monocytes or T cells on the PPD-induced IFN- $\gamma$ release by T cells co-cultured with different monocyte subsets ${ }^{\mathrm{a})}$

\begin{tabular}{|c|c|c|}
\hline Experiment & Co-cultured cells ${ }^{\mathrm{b})}$ (treatment) ${ }^{\mathrm{c})}$ & $\begin{array}{c}\text { IFN- } \gamma(\mathrm{pg} / \mathrm{ml}) \\
\text { PPD }\end{array}$ \\
\hline 1 & Unseparated MO & $6043 \pm 213$ \\
\hline \multirow[t]{4}{*}{2} & Unseparated MO & $5280 \pm 11$ \\
\hline & Unseparated MO (CFSE) $+\mathrm{T}$ & $6574 \pm 428$ \\
\hline & $\mathrm{CD}^{2} 4^{+} \mathrm{MO}$ & $2178 \pm 224$ \\
\hline & $\mathrm{CD}^{-} 4^{-} \mathrm{MO}(\mathrm{CFSE})+\mathrm{T}$ & $12830 \pm 511$ \\
\hline
\end{tabular}

a) Data shown are the mean values \pm SD of independent measurements of at least two dilutions performed from the same culture supernatant. The IFN- $\gamma$ release by unstimulated cells was always less than the detection limit $(<78 \mathrm{pg} / \mathrm{ml})$.

b) Unseparated monocytes (MO) as well as their CD64 ${ }^{+}$and CD64 subsets $\left(2.5 \times 10^{4}\right)$ were co-cultured with a constant number of T cells $\left(2 \times 10^{5}\right)$ in $250 \mu \mathrm{l}$ medium in the presence of $10 \mu \mathrm{g} / \mathrm{ml}$ PPD. IFN- $\gamma$ was measured in supernatants of 3 days cultures by ELISA.

c) Monocytes or T cells were preincubated with the fluorochrome CFSE $(20 \mu \mathrm{g} / \mathrm{ml})$ before co-culture.

Table 2. Comparison of unseparated monocytes and $\mathrm{CD} 64^{+}$and $\mathrm{CD}^{-}$subsets in their susceptibility to cell death in PPDactivated co-cultures with $T$ cells ${ }^{\text {a) }}$

\begin{tabular}{|c|c|c|c|c|}
\hline \multirow{2}{*}{$\begin{array}{l}\text { Experi- } \\
\text { ment }\end{array}$} & \multirow[b]{2}{*}{$\begin{array}{l}\text { Monocyte } \\
\text { subset }^{c)}\end{array}$} & \multicolumn{3}{|c|}{ Cell death (\% 7-AAD ${ }^{+}$monocytes) $)^{\mathrm{b})}$} \\
\hline & & Medium & PPD & $\begin{array}{c}\text { Ratio } \\
\text { (PPD/none) }\end{array}$ \\
\hline \multirow[t]{3}{*}{1} & Unseparated & 8,2 & 13,3 & 1,6 \\
\hline & $\mathrm{CD}^{+} 4^{+}$ & 31,9 & 56,5 & 1,8 \\
\hline & $\mathrm{CD}^{-} 4^{-}$ & 32,9 & 30,6 & 0,9 \\
\hline \multirow[t]{3}{*}{2} & Unseparated & 12,9 & 26,6 & 2,1 \\
\hline & $\mathrm{CD} 64^{+}$ & 7,7 & 43,6 & 5,7 \\
\hline & $\mathrm{CD}^{-} 4^{-}$ & 31,2 & 35,4 & 1,1 \\
\hline \multirow[t]{3}{*}{3} & Unseparated & 25,0 & 42,5 & 1,7 \\
\hline & CD $64^{+}$ & 8,8 & 20,9 & 2,4 \\
\hline & $\mathrm{CD}^{-} 4^{-}$ & 19,0 & 25,2 & 1,3 \\
\hline \multirow[t]{3}{*}{4} & Unseparated & 22,7 & 30,2 & 1,3 \\
\hline & $\mathrm{CD}^{+} 4^{+}$ & 19,9 & 39,3 & 2,0 \\
\hline & $\mathrm{CD}^{-} 4^{-}$ & 45,0 & 41,9 & 0,9 \\
\hline
\end{tabular}

a) Unseparated monocytes or their $\mathrm{CD} 64^{+}$and $\mathrm{CD} 64^{-}$subsets $\left(2.5 \times 10^{4}\right.$ cells $)$ were co-cultured with $\mathrm{T}$ cells $\left(2 \times 10^{5}\right)$ in $250 \mu \mathrm{l}$ medium in the presence or absence of $10 \mu \mathrm{g} / \mathrm{ml}$ PPD for 3 days.

b) 7-AAD staining and flow cytometric analysis were performed as described in Sects. 2.5 and 2.8 .

c) In experiments 1-3, monocytes and in Experiment 4, T cells were labeled with CFSE prior to co-culture with unstained monocytes or $\mathrm{T}$ cells.

compared to unstimulated samples. As depicted in Fig. 1, the reduction of the proportion of monocytes was more apparent in cultures to which $\mathrm{CD} 64^{+}$monocytes (reduction from $9.4 \%$ to $4.6 \%$ ) or unseparated (not shown) were added than in cultures containing $\mathrm{CD}^{-}$monocytes (reduction from $9.7 \%$ to $8.5 \%$ ). Similar results were obtained in PPD-activated co-cultures of elutriated monocytes and T cells labeled after $72 \mathrm{~h}$ of culture with a cocktail of $\mathrm{mAb}$ FITC-conjugated CD64, PE-conjugated antiCD3 and -CD2) instead of CFSE to differentiate between monocyte subsets and $T$ cells. When analyzed after staining with 7-AAD, the percentage of apoptotic cells was higher in the population of $\mathrm{CD}^{+} 4^{+} / \mathrm{CD}^{-} / \mathrm{CD} 2^{-}$than in $\mathrm{CD} 64 \%$ $\mathrm{CD} 3^{-} / \mathrm{CD} 2^{-}$cells. Thus, the viability of $\mathrm{CD}^{-} 4^{-}$monocytes was in this case also found to be higher as compared to $\mathrm{CD}^{+} 4^{+}$monocytes (not shown). Thereby we could exclude that the separation procedure per se caused the observed differences in monocyte apoptosis. Since anti-CD64 labeling was performed after culture, we could also rule out that antibody binding on $\mathrm{CD} 64^{+}$monocytes itself was responsible for their higher susceptibility to $T$ cellmediated apoptosis compared to $\mathrm{CD} 64^{-}$monocytes.

\subsection{Blocking of Fas antigen partially reduces killing of monocytes in co-cultures with PPD-activated $\mathbf{T}$ cells}

Since it is known that the interaction of CD95 (Fas) antigen and Fas ligand are involved in the mechanism of killing leading to apoptosis $[8,9]$, we tested the effect of blocking anti-Fas $\mathrm{mAb}$ in unseparated unstimulated or PPDactivated PBMC. Therefore, cells were cultured in the presence or absence of blocking anti-Fas mAb ZB4 [19] for $72 \mathrm{~h}$ and killing was again determined by 7-AAD labeling. In order to identify all monocytes (including CD64-) within the whole population, cells were stained with a cocktail of mAb (FITC-conjugated anti-HLA-DR, PEconjugated anti-CD3, -CD19 and -CD56) and only the HLA-DR ${ }^{+} / \mathrm{CD}^{-} / \mathrm{CD}^{-} 9^{-} \mathrm{CD} 56^{-}$population was analyzed. Similar to reconstituted monocyte/ $T$ cell co-cultures (Sect. 3.1), the number of 7-AAD ${ }^{+}$monocytes was enhanced in PPD-activated compared to unstimulated cultures (Table 3 ). In both experiments shown, the addition of anti-Fas mAb ZB4 reduced the number of 7-AAD ${ }^{+}$ monocytes in the PPD-stimulated cultures when compared to parallel cultures containing no $\mathrm{mAb}$ or an isotype control $\mathrm{mAb}$ in the same concentration. In experiment 1 the spontaneous killing was also reduced. In some donors who were found to be high responders to PPD $(>10 \mathrm{ng} / \mathrm{ml}$ IFN- $\gamma$ ) monocyte death was unaffected by the addition of mAb ZB4 in the same concentration (data not shown).

\subsection{Expression of Fas antigen on $\mathrm{CD64}^{+}$and $\mathrm{CD}^{-}$ monocytes}

Having found that monocyte killing by PPD-activated $T$ cells can be reduced by blocking anti-Fas $\mathrm{mAb}$, the differential susceptibility of monocyte subsets could be related to differential expression of CD95 (Fas) on CD64 ${ }^{+}$and $\mathrm{CD} 64^{-}$monocytes. Therefore we measured the expression 
Table 3. The inhibition of monocyte death by blocking anti-CD95 mAb ZB4 in PPD-activated cultures of PBMC ${ }^{\text {a) }}$

\begin{tabular}{lccc}
\hline & & \multicolumn{2}{c}{$\begin{array}{c}\text { Cell death (\% 7-AAD } \\
\text { monocytes) }\end{array}$} \\
Experiment & mAb & Medium & PPD \\
\hline 1 & - & 63 & 77 \\
& IgG1 & 57 & 72 \\
2 & ZB4 & 45 & 57 \\
& - & 51 & 75 \\
& IgG1 & 50 & 75 \\
& ZB4 & 53 & 67
\end{tabular}

a) PBMC ( $2 \times 10^{5}$ cells) were cultured in $200 \mu \mathrm{l}$ medium in the presence or absence of $10 \mu \mathrm{g} / \mathrm{ml}$ PPD and $1 \mu \mathrm{g} / \mathrm{ml} \mathrm{mAb}$ for 3 days.

b) 7-AAD staining and flow cytometric analysis were performed as described in Sects. 2.5 and 2.8 .

of Fas antigen on freshly isolated $\mathrm{CD} 64^{-}$and $\mathrm{CD} 64^{+}$monocytes and after their co-culture with $T$ cells in the presence of PPD. As shown in Table 4 for staining with anti-Fas $\mathrm{mAb}$ clone DX2, freshly isolated $(0 \mathrm{~h})$ as well as cultured $\left(16 \mathrm{~h}\right.$ and $72 \mathrm{~h}$ ) unseparated and CD64 and CD64 ${ }^{+}$monocytes contained comparable proportions of $\mathrm{CD}^{+} 5^{+}$monocytes. While in PPD-activated monocyte/T cell co-cultures the proportion of CD95-expression remained unchanged during a 72-h stimulation period, the antigen density per cell (given by mean fluorescence intensity; number in parenthesis) increased and was enhanced compared to unstimulated cultures in all monocyte populations to a similar degree. In addition $T$ cells of these cultures responded by increased expression of CD95 during the incubation times of $16 \mathrm{~h}$ and $72 \mathrm{~h}$ and due to stimulation with PPD. In T cells, both the proportion of $\mathrm{CD} 95^{+}$cells and antigen density per cell increased, irrespective of the monocyte subset (CD $64^{+}$and $\mathrm{CD} 64^{-}$) which was present in the culture (Table 4). In addition, immunofluorescence labeling with anti-CD95 mAb clone SB6-2B used for the induction of apoptosis (Sect. 3.4) revealed a comparable staining pattern of $T$ cells as well as on freshly isolated monocytes and their subsets (data not shown). Labeling with anti-Fas blocking $\mathrm{mAb}$ ZB4 also stained similar numbers of freshly isolated monocytes and T cells (not shown).

\subsection{Anti-Fas antibodies are not cytotoxic for CD64 monocytes}

Since $\mathrm{CD}^{+} 4^{+}$and $\mathrm{CD} 64^{-}$monocytes show similar CD95 (Fas antigen) expression (Sect. 3.3), we investigated whether $\mathrm{CD} 64^{+}$and $\mathrm{CD} 64^{-}$monocytes differentially respond to anti-Fas antibodies which are able to trigger apoptosis [8, 20, 22-24]. Therefore, first freshly isolated elutriated monocytes were incubated for $12 \mathrm{~h}$ with IgG3 anti-CD95 mAb clone SB6-2B. After incubation cells were counted and labeled with FITC-conjugated anti-CD64 $\mathrm{mAb}$ and a cocktail of mAb (CD3, CD2, CD19, CD56, all PE-conjugated) to exclude any cells which could contaminate the monocyte preparation during flow cytometric analysis. After exposure to 7-AAD, the multiple staining allowed gating and analysis of the viability (percentage of 7-AAD ${ }^{+}$) of $\mathrm{CD}^{+} 4^{+}$(FITC-green) and CD64- (not green, not PE-red) cells. As shown in Table 5, the $\mathrm{CD}^{+} 4^{+}$monocytes were more sensitive to anti-Fas mAb-mediated apoptosis which was indicated by the threefold higher percentage of $7-\mathrm{AAD}^{+}$cells in $\mathrm{CD}^{+} 4^{+}(47 \%)$ than in $\mathrm{CD}^{-}$ monocytes $(14.1 \%)$. In a separate experiment the anti-Fas $\mathrm{mAb}$ was added to sorted unseparated monocytes and to isolated $\mathrm{CD}^{+} 4^{+}$and $\mathrm{CD}^{-} 4^{-}$subsets (Fig. 2). In this case CD64- monocytes were also resistant to anti-Fas $\mathrm{mAb}$ mediated killing $\left(12.8 \% 7-\mathrm{AAD}^{+}\right.$compared to $7.9 \%$ in control cultures), whereas in unseparated and $\mathrm{CD} 64^{+}$ monocytes the proportion of 7-AAD ${ }^{+}$cells was markedly enhanced $\left(40.3 \%\right.$ in unseparated and $44.8 \%$ in $\left.\mathrm{CD}^{+} 4^{+}\right)$. Since both kinds of experiments revealed comparable results and, moreover, Fas-induced killing of $\mathrm{CD} 64^{+}$sorted and unseparated unstained monocytes (containing $>90 \%$ $\mathrm{CD}^{+} 4^{+}$cells) was identical, an influence of the isolation procedure or antibody binding on $\mathrm{CD} 64^{+}$monocytes per se can be excluded.

Table 4. Kinetics of CD95 (FAS antigen) expression on monocytes and T cells in PPD-stimulated co-cultures ${ }^{\text {a) }}$

\begin{tabular}{|c|c|c|c|c|c|c|c|}
\hline \multirow{2}{*}{$\begin{array}{l}\text { Time period of } \\
\text { co-culture } \\
\text { Monocyte } \\
\text { subset }\end{array}$} & \multirow[b]{2}{*}{ PPD } & \multicolumn{2}{|c|}{$0 \mathrm{~h}^{\mathrm{d})}$} & \multicolumn{2}{|c|}{$\mathrm{CD} 5^{+}$cells $(\%)^{\mathrm{b})}$} & \multicolumn{2}{|c|}{$72 \mathrm{~h}$} \\
\hline & & MO & $\mathrm{T}$ & MO & $\mathrm{T}$ & MO & $\mathrm{T}$ \\
\hline Unseparated & - & $95(56)$ & - & $88(53)^{e)}$ & $21(25)$ & $67(89)$ & $49(36)$ \\
\hline $\mathrm{CD} 64^{+}$ & - & $96(47)$ & - & $92(45)$ & $23(28)$ & $60(113)$ & $54(34)$ \\
\hline $\mathrm{CD}^{-} 4^{-}$ & - & $82(47)$ & - & $84(30)$ & $23(22)$ & $67(136)$ & $92(48)$ \\
\hline Unseparated & + & - & - & $87(69)$ & $40(22)$ & $84(309)$ & $97(90)$ \\
\hline CD64 ${ }^{+}$ & + & - & - & $88(74)$ & $49(24)$ & $85(296)$ & $97(80)$ \\
\hline $\mathrm{CD}^{-} 4^{-}$ & + & - & - & $78(57)$ & $48(27)$ & $82(371)$ & $97(79)$ \\
\hline \multirow[t]{2}{*}{$\mathrm{T}$ cells alone } & - & - & $30(29)$ & - & $19(28)$ & - & $37(34)$ \\
\hline & + & - & - & - & $23(20)$ & - & $33(31)$ \\
\hline
\end{tabular}

a) Data shown are from one out of three experiments performed (-: not done).

b) Cells were imunofluorescence labeled with anti-CD95 mAb clone DX2.

c) Unseparated monocytes or their CD64 $4^{+}$and $\mathrm{CD}_{64}^{-}$subsets $\left(2.5 \times 10^{4}\right)$ were co-cultured with $2 \times 10^{5} \mathrm{~T}$ cells in $250 \mu \mathrm{lmedium}$ in the presence or absence of $10 \mu \mathrm{g} / \mathrm{ml}$ PPD.

d) Freshly isolated cells were labeled without further cultivation.

e) Mean fluorescence intensity (channel number of logarithmic scale). 
Table 5. Comparison of the cytotoxic activity of anti-CD95 (APO-1) $\mathrm{mAb}$ on $\mathrm{CD}^{-} 4^{-}$and $\mathrm{CD} 64^{+}$subsets determined with the whole monocyte population by differential staining with $\mathrm{mAb}$

\begin{tabular}{|c|c|c|}
\hline \multirow[b]{2}{*}{ Monocyte subset $^{\text {a) }}$} & \multicolumn{2}{|c|}{ Cell death (\% 7-AAD ${ }^{+}$cells) } \\
\hline & - Anti-Fas mAb & + anti-Fas $\mathrm{mAb}$ \\
\hline Total monocytes & $6,6 \pm 0,6$ & $44,3 \pm 9,2$ \\
\hline $\mathrm{CD} 4^{+}$ & $6,1 \pm 2,2$ & $47,0 \pm 8,8$ \\
\hline $\mathrm{CD} 64^{-}$ & $13,8 \pm 1,2$ & $14,1 \pm 2,7$ \\
\hline
\end{tabular}

a) Elutriation-derived monocytes $\left(1 \times 10^{6} / 500 \mu \mathrm{l}\right.$ medium) were cultured for $12 \mathrm{~h}$ in the absence or presence of $10 \mu \mathrm{g} / \mathrm{ml}$ of APO-1 mAb (clone SB6-2B). Thereafter, cells were labeled with PE-conjugated (red) anti-CD3, -CD2,-CD19, -CD56 and FITC-conjugated (green) anti-CD64 mAb to distinguish between different monocyte subsets within the whole cell population. Subsequently, after preincubation with 7-AAD cell death was measured by flow cytometric analysis. During analysis unstained cells were considered as total monocytes, cells stained only green as $\mathrm{CD} 64^{+}$, and cells stained neither red nor green as CD64 monocytes. Data are the mean values \pm SD from three independent experiments.

\section{Discussion}

In cultures activated with recall antigens monocytes are eliminated by $\mathrm{CD}^{+} \mathrm{CD} 45 \mathrm{RO}^{+} \mathrm{T}$ lymphocytes which induce apoptosis of APC [10]. Since CD64 ${ }^{+}$and CD64monocyte subpopulations differ in their capacity to present PPD to autologous T cells, as shown previously [12], we investigated in this study whether $\mathrm{CD} 64^{+}$and $\mathrm{CD} 64^{-}$ monocyte subpopulations are equally susceptible to T cellmediated killing. It has been demonstrated that CD64monocytes are less efficiently killed by PPD-activated $\mathrm{T}$ cells than the $\mathrm{CD} 64^{+}$subset. This is based on data revealing that the viability and recovery of $\mathrm{CD} 64^{-}$monocytes were comparable in control and PPD-activated cultures. In contrast, in case of unseparated or $\mathrm{CD} 64^{+}$monocytes, the percentage of apoptotic cells was higher in PPDstimulated than in control cultures. It is generally accepted that $\mathrm{CD}^{+}$cytotoxic $\mathrm{T}$ cells eliminate APC by inducing

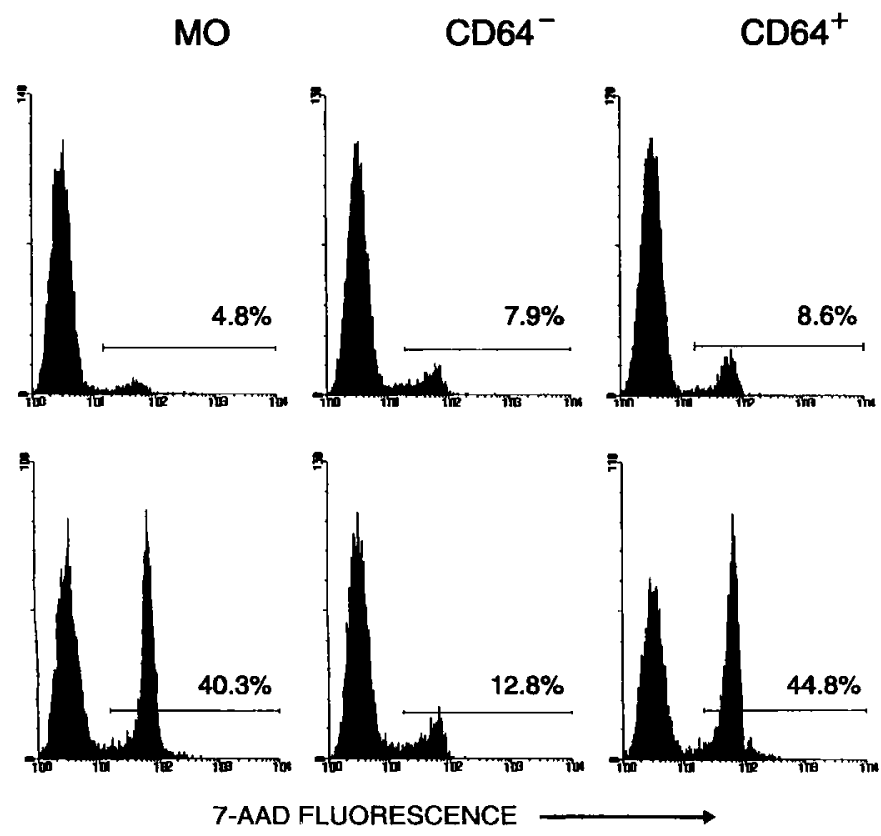

their apoptosis, probably due to interaction between CD95 (Fas) antigen and its ligand [7-9]. This also seems to be involved in our studies, since mAb blocking CD95 (Fas) partially reduced the killing of monocytes within PPDactivated PBMC of some skin test-positive donors. The question why killing was not completely inhibited and why CD95-blocking mAb was uneffective in PPD high responders is still unresolved. It might indicate that other killing principles are involved. Apoptosis induced by TNF$\alpha$ appears to be very unlikely in the case of human monocytes, since it has been shown recently that TNF- $\alpha$ prevents spontaneously occurring apoptosis in human monocyte cultures [25]. The perforin/granzyme pathway is the major killing mechanism of cytotoxic $\mathrm{CD8}^{+} \mathrm{T}$ cells. This pathway, however, seems to be of minor significance in cytotixic $\mathrm{CD}^{+} \mathrm{T}$ cells [7] which are the major mediators of monocyte killing in PPD-activated co-cultures [10]. In our study we did not investigate the possible contribution of the perforin/granzyme pathway, but we focussed our interest on the Fas-mediated killing by $\mathrm{CD}^{+} \mathrm{T}$ cells. The observed differences in the survival of monocyte subpopulations could be due to variable inducibility of cytotoxic $T$ cells in the presence of monocyte subsets, different expression of CD95 antigen on CD64 ${ }^{+}$and CD64- monocytes, or functional differences in pathways leading to cell apoptosis in monocyte subsets. Our data cannot be explained by a differential induction of cytotoxic $T$ cells by monocyte subsets, since $\mathrm{CD}^{-} 4^{-}$monocytes were also less efficiently eliminated in PPD-stimulated cultures of $T$ cells and unseparated monocytes, where $\mathrm{CD} 64^{+}$monocytes are in excess (more than $90 \%$ ) and could induce T cell cytotoxicity. In agreement with data reported by others $[22,23]$, in our hands almost all freshly isolated monocytes expressed CD95 (Fas antigen). This expression increased dramatically after culture (as judged from increase of fluorescence intensity), and $\mathrm{CD} 64^{+}$and $\mathrm{CD} 64^{-}$behaved comparably. Similarly, the expression of Fas antigen increased on cocultured T lymphocytes, irrespective of the monocyte subset present. Although we observed no substantial difference in the expression of CD95 antigen on CD64 ${ }^{+}$ and $\mathrm{CD} 64^{-}$monocyte subsets, the $\mathrm{CD} 64^{-}$monocytes were

control mAb

anti-CD95 mAb

Figure 2. Comparison of anti-CD95 (APO-1) mAb-induced killing of monocyte subsets. Unseparated monocytes (left), CD64- (middle) or $\mathrm{CD}^{+} 4^{+}$(right) monocytes were incubated with $10 \mu \mathrm{g} / \mathrm{ml}$ of anti-CD95 (APO-1) $\mathrm{mAb}$ clone SB6-2B for $12 \mathrm{~h}$, and after preincubation with 7-AAD flow cytometric analysis was performed. Histograms of viability measurements (7-AAD-positive cells) in control cultures treated with $10 \mu \mathrm{g} / \mathrm{ml}$ of an isotype-matched IgG3 Ki-67 mAb (upper row) and in the presence of APO-1 mAb (bottom) are shown. 
resistant to killing by IgG3 anti-CD95 $\mathrm{mAb}$ clone SB6-2B, suggesting that intracellular pathways leading to cell apoptosis may be different in $\mathrm{CD} 64^{+}$and $\mathrm{CD} 64^{-}$cell populations. The question of possible differences in intracellular pathways of $\mathrm{CD}^{+} 4^{+}$and $\mathrm{CD} 64^{-}$monocytes was not addressed directly in this study. Since cysteine proteases are supposed to be involved in apoptosis $[26,27]$, we tested IL-1 $\beta$ converting enzyme (ICE) as one of them. It is of interest that lysates derived from $\mathrm{CD} 64^{-}$monocytes are inactive when tested for the ability to cleave the IL- $1 \beta$ precursor, indicating that this monocyte subset may lack or contain less active ICE/CED-3 proteases (Loppnow et al., unpublished). Although the presence of ICE per se is not essential for cell apoptosis to occur [28-30], the finding suggests that the composition of cysteine proteases may differ in $\mathrm{CD}^{+} 4^{+}$and $\mathrm{CD} 64^{-}$monocyte subsets. We have shown that $\mathrm{CD}^{-} 4^{-}$monocytes may serve as potent APC, a finding which corresponds to high expression of MHC class II antigens [12] and of CD86 co-stimulatory molecule on these cells (E. Grage-Griebenow, in preparation). The data presented above indicate that the more efficient activation of $\mathrm{T}$ cells in the presence of $\mathrm{CD} 64^{-}$compared to $\mathrm{CD}^{+} 4^{+}$monocytes may also be associated with their higher resistance to cytotoxic $\mathrm{T}$ cells, as reported for antigenpresenting cell lines resistant to killing by activated $\mathrm{T}$ cells [6]. CD64 monocytes share many features of peripheral blood dendritic cells (DC) [31-34], as they are poorly phagocytic but very potent APC, have low expression of CD14 antigen, high expression of HLA-DR antigen [12], a phenotype similar to that of the $\mathrm{CD} 14^{+} / \mathrm{CD} 16^{+}$monocyte subset, as described by Ziegler-Heitbrock [35], and CD64monocytes express high levels of CD86 co-stimulatory molecule (E. Grage-Griebenow, in preparation). In addition, CD64 monocytes have high antiviral activity $[12,36]$, as described also for DC [32, 34]. Interestingly, reticular DC which are considered as very efficient APC are also not lysed by $\mathrm{CD} 4^{+}$cytotoxic cells (cited after Hahn et al. [7]). In this line our data point to the possibility that the resistance to killing by activated $T$ cells may be a common feature of efficient APC. This could have important biological significance, such as providing efficient (high expression of class II MHC and of co-stimulatory molecules) and longer lasting (resistance to Fas-mediated killing) presentation of peptides by non-phagocytic APC (DC, CD64 monocytes). Similar to the expression of MHC class II antigens and co-stimulatory molecules, resistance to killing by antigen-triggered $\mathrm{CD}^{+} \mathrm{T}$ cells is probably of utmost importance during induction of primary immune responses. In contrast, apoptosis of monocytes induced by phagocytosis of bacteria [37] or triggered by the contact with activated T cells ([10], CD $64^{+}$monocytes, this report) may be advantageous for the host to avoid an unnecessary immune response and to limit an infection by intracellular parasites [7]. Taken together, these data may also indicate different immunoregulatory tasks for $\mathrm{CD}^{-} 4^{-}$and $\mathrm{CD} 64^{+}$ monocytes, in the sense that the CD64- subset is more privileged for efficient and long lasting presentation of antigen to $\mathrm{T}$ cells, whereas the $\mathrm{CD} 64^{+}$subset is important for the removal of parasites by ingestion and cooperation with inflammatory (Th1) T cells.

We thank Mrs. R. Bergmann for the expert technical assistance in cytometric cell sorting and cytokine measurements, Mrs. E. Kaltenhäuser for cell preparation by counterflow centrifugation, Ms. $S$. Bark for carrying out Western blot analysis, and Mrs. R. Hinz for secretarial assistance. Thanks are extended to Dr. $H$. Gallati (Hoffmann-La Roche, Basel, Switzerland) for providing reagents

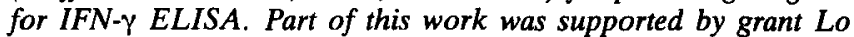
385/4-1 of the Deutsche Forschungs-gemeinschaft to $H$. $L$.

\section{References}

1 Davis, L. S. and Lipsky, P. E., Cell. Immunol. 1989. 118: 208.

2 Tite, J. P., Powell, M. B. and Ruddle, M. L., J. Immunol. 1985. 135: 25.

3 Ju, S.-T., DeKruyff, R. and Dorf, M. E., Cell. Immunol. 1986. 101: 613 .

4 Ozaki, S., York, J., Kawamura, H. and Berzofsky, J. A., Cell. Immunol. 1987. 105: 301.

5 Erb, P., Grogg, D., Troxler, M., Kennedy, M. and Fluri, M., J. Immunol. 1990. 144: 790.

6 Jones, B., Horowitz, J., Kaye, J., Killar, L., Bottomly, K. and Janeway, C. A. Jr., In Pernis, B., Silverstein, S. C. and Vogel, H. J. (Eds), Processing and Presentation of Antigens, Academic Press, London 1988, p. 291.

7 Hahn, S., Gehri, R. and Erb, P., Immunol. Rev. 1995. 146: 57.

8 Richardson, B. C., Lalwani, N. D., Johnson, K. J. and Marks, R. M., Eur. J. Immunol. 1994. 24: 2640.

9 Ashany, D., Song, X., Lacy, E., Nikolic-Zugic, J., Friedman, S. M. and Elkon, K. B., Immunology 1995. 92: 11225.

10 Pryjma, J., Zembala, M., Baran, J., Ernst, M. and Flad, H.D., Immunol. Lett. 1995. 46: 229.

11 Pryjma, J., Uracz, W. and Zembala, M., in Zembala, M. and Asherson, G. L. (Eds.), Human Monocytes, Academic Press, London 1989, p. 327.

12 Grage-Griebenow, E., Lorenzen, D., Fetting, R., Flad, H.-D. and Ernst, M., Eur. J. Immunol. 1993. 23: 3126.

13 Guyre, P. M., Graziano, R. F., Vance, B. A., Morganelli, P. M. and Fanger, M. W., J. Immunol. 1989. 143: 1650.

14 Abts, H., Emmerich, M., Miltenyi, S., Radbruch A. and Tesch, H., J. Immunol. Methods 1989. 125: 19.

15 Miltenyi, S., Müller, W., Weichel, W. and Radbruch, A., Cytometry 1990. 11: 231.

16 Weston, S. A. and Parish, C. R., J. Immunol. Methods 1990. 133: 87.

17 Lyons, A. B. and Parish, C. R., J. Immunol. Methods 1994. 171: 131.

18 Schmid, I., Krall, W. J., Uittenbogaart, C. H., Braun, J. and Giorgi, J. V., Cytometry 1992. 13: 204.

19 Liles, W. C., Kiener, P. A., Ledbetter, J. A., Aruffo, A. and Klebanoff, S. J., J. Exp. Med. 1996. 184: 429.

20 Trauth, B. C., Klas, C., Peters, A. M. J., Matzku, S., Moeller, P., Falk, W., Debatin, K.-M. and Krammer, P. H., Science 1989. 245: 301.

21 Gallati, H., J. Clin. Chem. Clin. Biochem. 1982. 20: 907.

22 Iwai, K., Miyawaki, T., Takizawa, T., Konno, A., Ohta, K., Yachie, A., Seki, H. and Taniguchi, N., Blood 1994. 84: 1201.

23 Shinohara, S., Sawada, T., Nishioka, Y., Tohma, S., Kisaki, T., Inoue, T., Ando, K., Ikeda, M., Fuji, H. and Ito, K., Cell. Immunol. 1995. 163: 303.

24 Um, H.-D., Orenstein, J. M. and Wahl, S. M., J. Immunol. 1996. 156: 3469 .

25 Dürrbaum-Landmann, I., Gercken, J., Flad, H.-D. and Ernst, M., Infect. Immun. 1996. 64: 5384.

26 Martin, S. J. and Green, D. R., Cell 1995. 82: 349.

27 Los, M., Van de Craen, M., Penning, L. C., Schenk, H., Westendorp, M., Baeuerle, P. A., Dröge, W., Krammer, P. H., Fiers, W. and Schulze-Osthoff, K., Nature 1996. 375: 81.

28 Nett-Fiordalski, M., Tomaselli, K., Russell, J. H. and Chaplin, D. D., J. Leukoc. Biol. 1996. 58: 717.

29 Darmon, A. J. and Bleackley, R. C., J. Biol. Chem. 1996. 271 : 21699.

30 Schlegel, J., Peters, I., Orrenius, S., Miller, D. K., Thornberry, N. A., Yamin, T.-T. and Nicholson, D. W., J. Biol. Chem. 1996. 271: 1841. 
31 Thomas, R., Davis, L. S. and Lipsky, P. E., J. Immunol. 1993. 150: 821 .

32 Ferbas, J. J., Toso, J. F., Logar, A. J., Navratil, J. S. and Rinaldo, C. R. Jr., J. Immunol. 1994. 152: 4649.

33 Thomas, R. and Lipsky, P. E., J. Immunol. 1994. 153: 4016.

34 Bhardwaj, N., Bender, A., Gonzalez, N., Bui, L. K., Garrett, M. C., Steinman, R. M., J. Clin. Invest. 1994. 94: 797.
35 Ziegler-Heitbrock, H. W. L., Fingerle, G., Ströbel, M., Schraut, W., Stelter, F., Schütt, C., Passlick, B. and Pforte, A., Eur. J. Immunol. 1993. 23: 2053.

36 Grage-Griebenow, E., Flad, H.-D. and Ernst, M., J. Leukoc. Biol. 1996. 60: 389.

37 Baran, J., Guzik, K., Hryniewicz, W., Ernst, M., Flad, H.-D. and Pryjma, J., Infect. Immun. 1996. 64: 4242. 